\title{
Yield and Nutritive Value of Sorghum, Maize and Soybean Forages Harvested in Southwestern Puerto Rico", 2
}

\author{
D. G. St. Louis, J. A. Arroyo Aguilú, A. Ramirez Ortiz and \\ R. E. McDowel/ ${ }^{3}$
}

ABSTRACT

\begin{abstract}
Six varieties of forage sorghum (Sorghum bicolor) and sorghum $\times$ sudangrass hybrids ( $S$. bicolor $\times S$. sudanese), six varieties of grain sorghum ( $S$. bicolor) and three varieties each of maize (Zea mays) and soybean (Glycine $\max$ ) were grown in $1.2 \times 3.7 \mathrm{~m}$ plots at the Lajas Experiment Substation. All plots were harvested in the boot, flower and dough stages. Ratoons of the sorghum varieties were also harvested after $\mathbf{4 5}$ days of regrowth until the stands diminished.

The forage sorghums and maize had higher yields of green and dry material than the grain sorghums. However, only the grain sorghums showed any significant increase in yield as the crop matured. All crops decreased in nutritive value with advance in age. In general, maize was higher in nutritive value than the forage sorghums.

Results indicated that forage sorghums can be recommended due to high yields of good quality forage on irrigated lands on the south coast. However, results with soybean forage were poor. It does not appear feasible to produce soybeans to enhance the crude protein content of forage pellets.
\end{abstract}

\section{INTRODUCTION}

Puerto Rico has a large dairy industry, the majority of the operations located in the northern half of the Island. Average maximum temperature is $31.1^{\circ} \mathrm{C}$; average minimum temperature is $18.3^{\circ} \mathrm{C}$. These temperature conditions should permit continuous growth of grasses for quality grazing. However, lower rainfall, shorter days and slightly cooler temperatures from January to March reduce pasture yields about $50 \%(9,15)$. Because of inadequate grazing in the winter months, the diarymen need supplementary forages. Commercial hay production from tropical grasses is

\footnotetext{
I Manuscript submitted to Editorial Board October 4, 1978.

${ }^{2}$ Data are taken in part from a thesis submitted by the senior author to the Graduate Faculty, Cornell University, Ithaca, N.Y., in partial fulfillment of the requirements for the degree of Doctor of Philosophy. The authors wish to thank Glenelg Dehydrators, Ellicott City, Maryland, for a grant used in partial support of the research, Dr. A. Sotomayor-Rios, ARS, USDA, Isabela, for recommendations on varieties and supplying the sorghum seeds, and personnel of the Soil and Water Division, ARS, USDA, Rio Piedras, for their consul-

${ }^{3}$ Former Research Assistant, Department of Animal Science, Cornell University, Ithaca, N.Y.; Nutritionist and Assistant Animal Husbandman, Animal Husbandry Department, Agricultural Experiment Station, University of Puerto Rico, Rio Piedras, and Lajas, P.R.; and Professor of International Animal Science, Department of Animal Science, Cornell University, Ithaca, N.Y., respectively.
} tation. 
expanding, but as in other tropical areas, there are problems for producing hay of high quality $(7,14,17)$. Some dairymen in Puerto Rico and the southern United States have found dehydrated forage pellets more suitable for supplementary feeding than grass hays (2). Currently, pelleted forages are all imported from the United States.

Although high yields of dry matter (DM) can be produced from tropical grasses(15), there are disadvantages to the use of rapid-growing, highyielding grasses, like Napier grass (Pennisetum purpureum) to produce a dehydrated pellet. When the grasses have reached a stage for high yield per cut, the leaf to stem ratio is less than desired, nutritive value is low, and the lower stems are hardened (3). Thus, the proper dehydration process is very difficult to accomplish, i.e. the leaves suffer severe heat damage before the stems are dry enough for pelleting, with resulting losses in protein digestibility (5). Another handicap to development of commercial dehydration with tropical grasses is that most grasses require vegetative propagation, which requires considerable time and expense.

The objective of this study was to assess the yield and nutritive value of forage and grain sorghum (Sorghum bicolor) varieties and sorghum $\times$ sudangras hybrids ( $S$. bicolor $\times S$. sudanense) as well as maize (Zea mays) and soybean (Glycine max) varieties for dehydrated pellet production for use in livestock feeding in Puerto Rico.

\section{PROCEDURE}

Six varieties of forage sorghum hybrids and sorghum $\times$ sudangrass hybrids and three varieties each of maize and soybean were planted at the University of Puerto Rico Agricultural Experiment Substation at Lajas, located on the southwestern coast at lat. $18^{\circ} \mathrm{N}$ and long. $67^{\circ} \mathrm{W}$. The six grain sorghum varieties were planted in March 1975. Plots measuring $1.2 \times 3.7 \mathrm{~m}$ were laid out in a partially balanced incomplete block design so that each variety of forage sorghum, maize and soybeans was replicated four times. Each grain sorghum variety had three replicas. All plots were fertilized when the seedbeds were prepared and after each harvest, with a $15-5-10$ fertilizer analysis equivalent to $4,480 \mathrm{~kg} / \mathrm{ha} / \mathrm{yr}$.

The sorghum and maize varieties were planted in two rows per plot, 76 $\mathrm{cm}$ apart. Two seeds were placed at $15 \mathrm{~cm}$ intervals in the rows for a total of 24 plants. The soybeans had three rows per plot, $46 \mathrm{~cm}$ apart, with two seeds at $10 \mathrm{~cm}$ intervals. In each row, there were at least 36 plants. All plots were irrigated with an overhead sprinkler for $1 \mathrm{~h}$ at 13-day intervals. This was calculated to deliver 3.8 to $5.0 \mathrm{~cm}$ of water per irrigation.

One-third of each sorghum, maize and soybean plot was harvested when the plants were judged to be in the boot, flower and dough stages (46, 56 and 81 days after planting). These harvests were assigned at random to either end or the middle of the plots. Following the dough- 
stage harvest of the sorghums, the regrowth or ratoons of all plots were harvested every 45 days until the plant stand and yield decreased to a point where reseeding was recommended. The plants were harvested from March 1975 to April 1976.

Plants were harvested at an approximate height of $10 \mathrm{~cm}$ above soil level. They were weighed in the field and subsampled. Samples were oven-dried at $60^{\circ} \mathrm{C}$ for 2 to 3 days and ground in a Wiley mill to pass through a 1-mm screen. Dry matter (DM) was determined on all samples.

Crude protein (CP) content was determined by the Technicon microanalyzer (12). Neutral-detergent fiber (NDF), acid-detergent fiber (ADF), permanganate lignin $(\mathrm{L})$, silica $(\mathrm{Si})$, and in vitro dry matter digestibility (IVTD) were determined by the Goering and Van Soest's techniques (6). Estimated apparent digestibility (EAD) was determined from IVTD data or estimated by regression on $\mathrm{ADF}(6)$.

For each crop, yield and chemical composition data were analyzed in a two-way factorial design, including interaction, the factors being varieties and harvest. Scheffe's criterion (13) was used to compare subclass and class means.

\section{RESULTS AND DISCUSSION}

\section{FORAGE SORGHUM}

The forage sorghums showed potential for more DM yield than maize or the grain sorghum varieties tested. The best varieties for yields were SX-16, SX-17 and Pioneer 988 (table 1). While these three varieties were significantly higher in yield, they did not differ significantly from each other. DM yields were expected to increase with maturity $(4,16)$, but this was not the case (table 2).

The second and third ratoons were significantly higher in yields of both green forage (GF) and DM than the other ratoons (table 2). The change in yields may have been influenced by soil moisture. During the first two growth periods, the amount of irrigation may have been insufficient to promote rapid growth. During the growth of the fourth and fifth ratoons, summer winds may have interfered with water distribution by the sprinklers. The interaction of variety and ratoon was significant. This was a result of greater increase in yield for the second and third ratoons for varieties $\mathrm{SX}-16$ and $\mathrm{SX}-17$. It may be that these two varieties have the best potential for forage yield, when soil moisture is not limiting.

The three best varieties of the forage sorghums (SX-16, SX-17, Pioneer 988) for yield were also the best in nutritive value as estimated from chemical composition (table 1). They were lowest in NDF, ADF and L but they were not better in digestibility (IVTD and EAD).

Measures of chemical composition were not definitive in determining 
the effect of harvest stage on feeding value. While the first harvest (boot stage) had somewhat higher feeding value, the later ratoons of approximately the same age ( 45 days) did not differ significantly in ADF and IVTD from the flower and dough stage cuts (table 2). The forage sorghum varieties were, in general, best in nutritive value when yields were high. However, in the fourth ratoon, yields were lower than for the third ratoon (table 2) but quality improved as estimated from CP and ADF. Records were not kept of plant height or density at the time of harvest, but these may have affected quality. For example, the fourth ratoon may have been slow to regrow, had a lower plant density or not received adequate water until just prior to harvest, which would have reduced yield and raised

TABLE 1.-Yield, chemical composition and digestibility of six forage sorghum varieties

\begin{tabular}{|c|c|c|c|c|c|c|}
\hline & Sordan 80 & SX.16 & Pioneer 988 & Trudan 6 & SX-17 & SX-15 \\
\hline \multicolumn{7}{|c|}{$\mathrm{Kg} / \mathrm{ha} /$ harvest } \\
\hline $\mathrm{GF}^{\mathrm{l}}$ & $30,220_{b, c^{2}}$ & $42,570_{u}$ & $36,020_{b}$ & $23,560_{d}$ & $42,610_{\mathrm{a}}$ & $24,100_{\mathrm{c}, \mathrm{d}}$ \\
\hline DM & $8,830_{b, c}$ & $11,140_{\mathrm{a}}$ & $10,130_{a, b}$ & $6,640_{\mathrm{d}}$ & $11,030_{\mathrm{a}}$ & $6,970_{c, \mathrm{~d}}$ \\
\hline $\mathrm{CP}$ & 650 & 870 & 780 & 520 & 920 & 560 \\
\hline EAD & 5,130 & 6,610 & 5,940 & 3,770 & 6,640 & 3,930 \\
\hline \multicolumn{7}{|c|}{ Percent } \\
\hline $\mathrm{NDF}$ & $61.4_{h, c}$ & $55.9_{\mathrm{a}}$ & $57.9_{\mathrm{a}, \mathrm{b}}$ & $61.0_{b, c}$ & $60.4_{u, b}$ & $65.6_{c}$ \\
\hline $\mathrm{ADF}$ & $41.0_{\mathrm{b}}$ & $38.7_{d}$ & $38.9_{a}$ & $40.6_{\mathrm{b}}$ & $38.8_{a}$ & $41.3_{\mathrm{h}}$ \\
\hline $\mathrm{L}$ & 7.0 & 6.7 & 6.4 & 7.1 & 6.3 & 7.1 \\
\hline $\mathrm{Si}$ & 3.6 & 3.9 & 3.9 & 4.1 & 4.2 & 4.5 \\
\hline $\mathrm{CP}$ & $7.3_{\mathrm{b}}$ & $7.8_{\mathrm{a}, \mathrm{b}}$ & $7.7_{\mathrm{a}, \mathrm{b}}$ & $7.8_{\mathrm{a}, \mathrm{h}}$ & $8.4_{a}$ & $7.3_{\mathrm{R}, \mathrm{h}}$ \\
\hline IVTD & $75.3_{\mathrm{a}, \mathrm{b}}$ & $75.7_{\mathrm{a}, \mathrm{b}}$ & $75.0_{\mathrm{h}}$ & $73.4_{\mathrm{b}, \mathrm{c}}$ & $76.4_{u}$ & $72.3_{c}$ \\
\hline EAD & $58.1_{a, b}$ & $59.3_{\mathrm{a}, \mathrm{b}}$ & $58.7_{\mathrm{a}, \mathrm{b}}$ & $56.8_{\mathrm{b}}$ & $60.2_{a}$ & $56.2_{\mathrm{b}}$ \\
\hline
\end{tabular}

${ }^{1} \mathrm{GF}$, green forage; DM, dry matter; CP, crude protein; EAD, estimated apparent digestibility; NDF, neutral-detergent fiber; $\mathrm{ADF}$, acid-detergent fiber; L, lignin; Si, silica; IVTD, in vitro true digestibility.

${ }^{2}$ Mean values in the same row with one or more letters in common do not differ significantly at the $5 \%$ level.

quality. The higher yielding varieties also being best in quality supports this hypothesis. Edwards et al. (4) also found in Tennessee that Sudax SX-11 DM digestibility was more related to plant height and percentage leaves and stems than to either regrowth time or cutting height management.

\section{GRAIN SORGHUM}

Variety differences were significant for GF yield but not for the other three yield estimates (table 3). Stage of maturity (boot, flower, dough) had a significant effect on DM yield (table 4), which was not the case for forage sorghum, due to differences in crop moisture requirements and available soil moisture. 
TABLE 2.-Yield, chemical composition, and digestibility of forage sorghum varieties by harvest stage and ratoon cuttings at 45-day intervals

\begin{tabular}{|c|c|c|c|c|c|c|c|c|}
\hline & \multicolumn{3}{|c|}{ Harvest stage } & \multicolumn{5}{|c|}{ Ratoon } \\
\hline & Boot & Flower & Dough & 1 & 2 & 3 & 4 & 5 \\
\hline \multicolumn{9}{|c|}{$K g / h a / h a r v e s t$} \\
\hline $\mathrm{GF}^{1}$ & $32,800_{b, c^{2}}$ & $23,070_{c, \mathrm{~d}}$ & $23,870_{\mathrm{c}, \mathrm{d}}$ & $36,830_{\mathrm{b}}$ & $53,680_{2}$ & $57,570_{\mathrm{a}}$ & $21,210_{\alpha}$ & $17,460_{\mathrm{d}}$ \\
\hline DM & $9,890_{b}$ & $8,450_{\mathrm{h}}$ & $9,280_{\mathrm{h}}$ & $8,850_{h}$ & $12,980_{\mathrm{a}}$ & $14,730_{\mathrm{a}}$ & $3,920_{c}$ & $4,860_{c}$ \\
\hline $\mathrm{CP}$ & 1,030 & 520 & 450 & 560 & 920 & 1,480 & 470 & 290 \\
\hline $\mathrm{EAD}$ & 6,430 & 5,070 & 5,040 & 5,310 & 7,130 & 8,200 & 2,240 & 2,870 \\
\hline \multicolumn{9}{|c|}{ Percent } \\
\hline $\mathrm{NDF}$ & & 59.9 & 61.3 & & & & & \\
\hline $\mathrm{ADF}$ & $38.9_{\mathrm{q}, \mathrm{b}}$ & $38.0_{\mathrm{a}}$ & $40.8_{c, d}$ & $38.3_{\mathrm{a}, \mathrm{h}}$ & $39.1_{a, b}$ & $42.6_{\mathrm{e}}$ & $41.6_{\mathrm{d}, \mathrm{e}}$ & $39.8_{\mathrm{b}, \mathrm{c}}$ \\
\hline L & $6.9 \mathrm{~b}$ & $6.2_{\text {в }}$ & $7.7 c$ & & & & & \\
\hline $\mathrm{Si}$ & $3.3_{\mathrm{d}}$ & $4.3_{\mathrm{b}}$ & $4.1_{h}$ & & & & & \\
\hline $\mathrm{CP}$ & $10.4 \mathrm{~h}$ & $6.0_{c, d}$ & $4.8_{d}$ & $6.3_{c}$ & $7,0 \mathrm{c}$ & $10.1_{h}$ & $12.0_{\mathrm{a}}$ & $5.9_{\mathrm{c}, \mathrm{d}}$ \\
\hline IVTD & $79.6_{d}$ & $75.5_{\mathrm{b}}$ & $71.3_{c}$ & $75.4 \mathrm{~b}$ & $71.8_{c}$ & & & \\
\hline $\mathrm{EAD}$ & $65.0_{\mathrm{a}}$ & $59.9_{\mathrm{h}}$ & $54.4 \mathrm{~d}$ & $59.9 \mathrm{~b}$ & $55.0_{c, d}$ & $55.8_{\mathrm{b}, \mathrm{c}, \mathrm{d}}$ & $57.0_{\mathrm{b}, \mathrm{c}, \mathbf{d}}$ & $59.0_{\mathrm{b}, \mathrm{c}}$ \\
\hline
\end{tabular}

' GF, green forage; DM, dry matter; CP, crude protein; EAD, estimated apparent digestibility; NDF, neutral-detergent fiber; ADF, aciddetergent fiber; L, lignin; Si, silica; IVTD, in vitro digestibility.

${ }^{2}$ Mean values in the same row with one or more letters in common do not differ significantly at the $5 \%$ level. 
Variety, stage of harvest or ratoon number made little difference in the estimates of nutritional value. The lowest value for $\mathrm{L}(\mathrm{C}-42)$, the highest for IVTD (NK-279) and for CP (E-56) occurred in different varieties (table 3 ). The boot stage tended to have higher nutritive value than the later stages as determined by $\mathrm{L}, \mathrm{IVTD}$ and $\mathrm{CP}$. As occurred with the forage sorghums, some ratoons, which were close in age to the boot stage, were significantly lower than the boot stage in several measures of nutritive value (table 4).

\section{MAIZE}

Variety differences were significant only for yields of GF and DM, as well as percentage of $\mathrm{L}$ and NDF (table 5). Maize followed the same trend

TABAE 3.-Yield, chemical composition, and digestibility of six grain sorghum varieties

\begin{tabular}{|c|c|c|c|c|c|c|}
\hline & NK 266 & $\mathrm{C}-42$ & $\operatorname{Tam} 680$ & NK-279 & E-56 & Pioneer 8311 \\
\hline \multicolumn{7}{|c|}{$\mathrm{Kg} / \mathrm{ha} / \mathrm{harvest}$} \\
\hline$G F^{\prime}$ & $26,000_{\mathrm{a}, \mathrm{b} z}$ & $24,660_{\mathrm{a}, \mathrm{h}}$ & $26,810_{a, b}$ & $28,740_{u}$ & $25,130_{\mathrm{a}, \mathrm{h}}$ & $23,090_{h}$ \\
\hline DM & 6,570 & 5,990 & 6,790 & 6,880 & 6,390 & 6,280 \\
\hline $\mathrm{CP}$ & 630 & 580 & 540 & 650 & 670 & 580 \\
\hline EAD & 3,810 & 3,470 & 3,880 & 4,080 & 3,680 & 3,520 \\
\hline \multicolumn{7}{|c|}{ Percent } \\
\hline NDF & 64.5 & 64.6 & 64.4 & 65.0 & 66.0 & 66.1 \\
\hline $\mathrm{ADT}$ & 38.2 & 37.9 & 38.9 & 38.2 & 38.2 & 38.2 \\
\hline $\mathbb{L}$ & $6.4_{n, b}$ & $6.2 \mathrm{a}$ & 6.8 & $6.9_{\mathrm{b}}$ & $6.9_{\mathrm{b}}$ & $6.9 \mathrm{~b}$ \\
\hline $\mathrm{Si}$ & 3.9 & 4.0 & 3.1 & 3.9 & 3.9 & 3.5 \\
\hline $\mathrm{CP}$ & $9.7_{\mathrm{b}}$ & $9.7_{\mathrm{h}}$ & $8.0_{b}$ & $9.4_{\mathrm{b}}$ & $10.4_{n}$ & $9.2_{\mathrm{a}}$ \\
\hline IVTD & $74.8_{u, b}$ & $74.7_{\mathrm{a}, \mathrm{h}}$ & $73.1_{\text {a.h }}$ & $75.5_{\mathrm{a}}$ & $73.9_{\mathrm{a}, \mathrm{b}}$ & $72.1_{\mathrm{h}}$ \\
\hline $\mathrm{EAD}$ & 58.2 & 53.1 & 57.2 & 59.2 & 57.6 & 56.1 \\
\hline
\end{tabular}

' GF, green forage; DM, dry matter; CP, crude protein; EAD, estimated apparent digestibility; NDF, neutral-detergent fiber; $\mathrm{ADF}$, acid-detergent fiber; L, lignin; Si, silica; IVTD, in vitro true digestibility.

${ }^{2}$ Mean values in the same row with one or more letters in common do not differ significantly at the $5 \%$ level.

as the forage sorghum varieties by yielding significantly more GF and DM in the boot stage, contrary to expectations. The plants cut in the dough stage were significantly lower than the other two stages in feeding value as indicated by NDF, ADF, L and IVTD. It was expected that the feeding quality of the whole maize plant would increase with maturity due to a proportionally greater increase in grain as nutritive value of the stem and leaf declined. A possible explanation for the lower quality is that soil moisture may have been limiting at the time of ear formation.

\section{SOYBEAN}

The three soybean varieties did not perform well. The first plantings did not produce satisfactory stands; therefore, they had to be replanted. 
TABLE 4-Yield, chemical composition, and digestibility of grain sorghum varieties by harvest stages of ratoon cuttings at 45-day intervals

\begin{tabular}{|c|c|c|c|c|c|c|c|c|}
\hline & \multicolumn{3}{|c|}{ Harvest stage } & \multicolumn{5}{|c|}{ Ratoon } \\
\hline & Boot & Flower & Dough & 1 & 2 & 3 & 4 & 5 \\
\hline \multicolumn{9}{|c|}{$\mathrm{Kg} / \mathrm{ha} / \mathrm{harvest}$} \\
\hline $\mathrm{GF}^{\mathrm{i}}$ & $27,370_{\mathrm{h} 2}$ & $28,160_{b}$ & $29,810_{\mathrm{h}}$ & $31,790_{b}$ & $38,960_{u}$ & $15,600_{c}$ & $19,640_{\mathrm{c}}$ & 14,590 \\
\hline DM & $6,460_{\mathrm{h}, \mathrm{c}}$ & $7,510_{\mathrm{h}, \mathrm{c}}$ & $9,010_{\mathrm{a}}$ & $7,940_{\mathrm{a}, \mathrm{b}}$ & $7,420_{\mathrm{a}, \mathrm{h}, \mathrm{c}}$ & $4,190_{\mathrm{b}, \mathrm{c}}$ & $5,670_{c, d}$ & $3,630_{\mathrm{e}}$ \\
\hline $\mathrm{CP}$ & 740 & 720 & 740 & 670 & 850 & 360 & 470 & \\
\hline EAD & 2,310 & 4,240 & 4,910 & 4,350 & 4,570 & 2,360 & 3,300 & - \\
\hline \multicolumn{9}{|c|}{ Percent } \\
\hline $\mathrm{NDF}$ & $64.6_{\mathrm{u}}$ & $64.4_{\mathrm{a}}$ & - & $66.4_{\mathrm{b}}$ & - & - & - & - \\
\hline $\mathrm{ADF}$ & $37.4_{\mathrm{a}}$ & $38.1_{\mathrm{t}, \mathrm{b}}$ & $37.0_{a}$ & $39.8_{\mathrm{h}}$ & 38.4 & $39.6 \mathrm{~b}$ & $37.5_{\mathrm{a}}$ & - \\
\hline $\mathrm{L}$ & $6.5_{\mathrm{a}}$ & $7.2 \mathrm{~b}$ & $6.6_{\mathrm{a}}$ & - & - & - & - & - \\
\hline $\mathrm{Si}$ & $3.8_{\mathrm{a}}$ & $3.3_{\mathrm{a}}$ & $3.9_{\mathrm{B}}$ & - & - & - & - & - \\
\hline $\mathrm{CP}$ & $11.6_{\mathrm{a}}$ & $9.7_{\mathrm{a}, \mathrm{b}}$ & $8.1_{b}$ & $8.4 \mathrm{~h}$ & $11.4_{k}$ & $8.3_{\mathrm{h}}$ & $8.3_{\mathrm{b}}$ & - \\
\hline IVTD & $77.7 \mathrm{a}$ & $72.9 \mathrm{~b}$ & $71.4_{\mathrm{b}}$ & $71 . \mathrm{h}_{\mathrm{h}}$ & $76.9_{\mathrm{a}}$ & - & - & - \\
\hline $\mathrm{EAD}$ & $62.5_{\mathrm{a}}$ & $56.3_{\mathrm{h}}$ & $54.5_{\mathrm{b}}$ & $54.8 \mathrm{~h}$ & $61.8_{u}$ & $56.3_{\mathrm{h}}$ & $57.9_{\mathrm{b}}$ & - \\
\hline \multicolumn{9}{|c|}{$\begin{array}{l}\text { ' GF, green forage; DM, dry matter; } \mathrm{CP} \text {, crude protein; EAD, estimated apparent digestibility; NDF, neutral-detergent fiber; ADF, ac } \\
\text { detergent fiber; L, lignin; Si, silica; IVTD, in vitro true digestibility. } \\
{ }^{2} \text { Mean values in the same row with one or more letters in common do not differ significantly at the } 5 \% \text { level. }\end{array}$} \\
\hline
\end{tabular}


Harvest was reduced to one stage (43 days) since yields were low. Variety differences were not significant in any of the traits measured (table 6). In spite of the low yields, the CP and IVTD values showed good feeding value.

The low yields of the soybean forage are probably attributed to the agronomic problems encountered at Lajas, as other experiments with soybean have shown that good forage yields can be obtained. In Nigeria, for example, where soybean yielded up to $5,260 \mathrm{~kg}$ of DM and $857 \mathrm{~kg}$ of $\mathrm{CP}$ per ha, the highest yield compared favorably with that of five other legume forages and cultivars of pigeon peas (Cajanus cajan) (1).

TABLE 5.-Yield, chemical composition, and digestibility of three maize varieties and three harvest stages

\begin{tabular}{|c|c|c|c|c|c|c|}
\hline & \multicolumn{3}{|c|}{ Variety } & \multicolumn{3}{|c|}{ Harvest Stage } \\
\hline & $\begin{array}{c}\text { Pioneer } \\
306 \mathrm{~B}\end{array}$ & Funic & $\begin{array}{c}\text { Diente de } \\
\text { caballo }\end{array}$ & Boot & Silking & Dough \\
\hline \multicolumn{7}{|c|}{$K g / h a$} \\
\hline $\mathrm{GF}^{\mathrm{l}}$ & $33,720_{\mathrm{a}^{2}}$ & $19,120_{\mathrm{b}}$ & $29,520_{\mathrm{a}}$ & $35,490_{\mathrm{a}}$ & $22,130_{h}$ & $24,750_{h}$ \\
\hline $\mathrm{DM}$ & $11,480_{\mathrm{a}}$ & $6,120_{\mathrm{h}}$ & $9,640_{\mathrm{a}}$ & $10,310_{\mathrm{a}}$ & $7,730_{\mathrm{b}}$ & $9,210_{\mathrm{h}, \mathrm{c}}$ \\
\hline $\mathrm{CP}$ & 690 & 470 & 540 & 960 & 430 & 450 \\
\hline $\mathrm{EAD}$ & 7,170 & 3,950 & 6,050 & 6,990 & 6,120 & 5,290 \\
\hline \multicolumn{7}{|c|}{ Percent } \\
\hline NDF & $60.9_{\mathrm{b}}$ & $60.2_{\mathrm{a}, \mathrm{b}}$ & $58.5_{\mathrm{a}}$ & $58.9_{\mathrm{a}}$ & $58.6_{\mathrm{a}}$ & $62.0_{b}$ \\
\hline $\mathrm{ADF}$ & $35.3_{\mathrm{a}}$ & $33.9_{a}$ & $33.3_{\mathrm{a}}$ & $33.2_{\mathrm{a}}$ & $33.4_{a}$ & $36.5_{\mathrm{b}}$ \\
\hline $\mathbf{L}$ & $5.4_{\mathrm{b}}$ & $4.4_{\mathrm{a}, \mathrm{h}}$ & $4.9_{\mathrm{a}}$ & $4.8_{\mathrm{u}}$ & $4.4_{\mathrm{a}}$ & $5.6 \mathrm{~h}$ \\
\hline $\mathrm{Si}$ & 3.0 & 2.6 & 3.1 & 2.8 & 2.9 & 3.0 \\
\hline $\mathrm{CP}$ & $6.1_{\mathrm{a}, \mathrm{b}}$ & $7.7 \mathrm{a}$ & $5.7_{\mathrm{b}}$ & $9.4_{\mathrm{a}}$ & $5.6 \mathrm{~h}$ & $4.4 \mathrm{k}$ \\
\hline IVTD & $77.7 \mathrm{a}$ & $79.2_{\mathrm{a}}$ & $78.0_{\mathrm{a}}$ & $81.8_{\mathrm{a}}$ & $79.3_{\mathrm{a}}$ & $73.7_{b}$ \\
\hline EAD & $62.4_{\mathrm{a}}$ & $64.4_{a}$ & $62.9_{\mathrm{a}}$ & $67.8_{\mathrm{a}}$ & $64.5_{a}$ & $57.4_{b}$ \\
\hline
\end{tabular}

' $\mathrm{GF}$, green forage; DM, dry matter; CP, crude protein; EAD, estimated apparent digestibility; NDF, neutral-detergent fiber; ADF, acid-detergent fiber; L, lignin; Si, silica; IVTD, in vitro true digestibility.

${ }^{2}$ Mean values in the same row with one or more letters in common do not differ significantly at the $5 \%$ level.

\section{POTENTIAL FOR DEHYDRATION}

The results indicate that several varieties of maize and forage sorghum have good yields and are adequate in nutritive value for use as a dehydrated forage in Puerto Rico. It is risky, however, to predict yields in $\mathrm{kg}$ per ha based on plots of $4.5 \mathrm{~m}^{2}$ because control of environmental factors, such as weed, pest and water control is simpler in small areas. Nevertheless, the yields compare favorably to other trials of larger plantings with forage sorghum in Puerto Rico. At the Isabela Substation (10), Grazer A was the superior variety but three of the varieties used in this study, SX-16, SX-17 and Pioneer 988, were nearly as good in yield. At the Corozal Substation (10), the rankings for DM yields were Sordan 
80, Grazer A, SX-17, SX-16, SX-15, Trudan 6, Pioneer 988, and Millo Blanco (a local variety). All varieties were grown under natural rainfall at Corozal; thus yields were somewhat lower (1157 to $1667 \mathrm{~kg}$ per ha). In Southwestern Puerto Rico, forage sorghum is being grown for commercial hay production. Six cuttings, at approximately 45 -day intervals, produced $9,800 \mathrm{~kg}$ of hay in about 300 days. At the same site, Stargrass (Cynodon nlemfuensis) yielded $7,100 \mathrm{~kg}$ of hay per acre in three cuttings or $2,600 \mathrm{~kg}$ per cut, indicating that grass could outyield sorghum on the south coast of Puerto Rico on an annual basis.

Fertilized grass pastures average about $55 \%$ in apparent digestibility $(9,15)$. On this basis, the forage and grain sorghum would be acceptable (tables 1 and 3). However, harvesting sorghum prior to its reaching the dough stage would be recommended, whereas maize harvested in the dough stage would still provide a high quality forage. The grain sorghum

TABLE 6.-Yield, crude protein and in vitro digestibility of three soybean varieties

\begin{tabular}{lrrrr}
\hline & \multicolumn{3}{c}{ Variety } & Hardee \\
\cline { 2 - 4 } & Jupiter & Biloxi & \\
GF & & $K g / h a$ & & 1390 \\
DM & 2690 & & 2240 & 630 \\
CP & 1190 & & 1100 & 105 \\
& 158 & & 188 & \\
CP & & Percent & & 16.6 \\
IVTD & 13.3 & & 17.1 & 76.6 \\
\hline
\end{tabular}

${ }^{1} \mathrm{GF}$, green forage; DM, dry matter; CP, crude protein; IVTD, in vitro true digestibility.

varieties tested were lower in nutritive value than the varieties of forage sorghum or maize.

Some of the maize varieties had yields per cut as high as the sorghums, but the costs of repeat planting would make the investment in maize pellets higher. Production costs are beyond the scope of this study but economic value due to quality should be considered. Hibbs and Conrad (8) recommended a formula based on the combined estimated net energy and digestible protein in a feed and current market price for maize grain and soybean meal. Two formulas were derived by assuming that the summative estimation of digestibility (6) equals TDN and by using Morrison's (11) values for maize grain and soybean meal: $(100 \mathrm{x}-56 \mathrm{y}) / 44$

$-\mathrm{b}$ and $56 \mathrm{y}-\mathrm{b}(11.0727) / 39.9840=\mathrm{c}$,

where;

$\mathrm{x}=$ price per $\mathrm{kg}$ of soybean meal,

$\mathrm{y}=$ price per $\mathrm{kg}$ of maize grain, 
$\mathrm{b}=$ value per $\mathrm{kg}$ of $\mathrm{CP}$

$c=$ value per $\mathrm{kg}$ of nitrogen-free $\mathrm{EAD}$

When the digestibility and CP of a feed is known, its value in relation to maize and soybean meal is the sum of $b$ and $c$. For example, if the price per ton for maize were $\$ 131$ and for soybean meal $\$ 241, b$ would equal $\$ 381$ per $\mathrm{kg}$ of $\mathrm{CP}$ and c would equal $\$ 0.78 \mathrm{per} \mathrm{kg}$ of nitrogen-free EAD. For forage sorghum containing $8.63 \% \mathrm{CP}$ and $58.60 \%$ digestibility, its value would be $\$ 3.29$ plus $\$ 3.90$ or $\$ 7.19$ per $100 \mathrm{~kg}$. Similarly, if whole maize plant forage has the same $\mathrm{CP}$ percentage but is $66 \%$ digestible, its value would be $\$ 7.76$ per $100 \mathrm{~kg}, \$ 0.57$ per $100 \mathrm{~kg}$ more than forage sorghum. If the values obtained in this study reflect true differences in quality that would be paid by dairymen, pellet producers could afford $\$ 6.37$ per harvest per $\mathrm{kg}$ additional costs for maize. Still, the forage sorghums have the advantage of ratoons. If 2 weeks are required between harvest and reseeding of successive maize and sorghum crops, and six 45day harvests were taken from each forage sorghum planting, the forage sorghum could provide about eight harvests annually compared to six for maize. Part of the time lag for maize could possibly be offset by no-till plantings.

Another method for comparing yield and quality is to express yield in terms of $\mathbb{E A D}$ and $\mathrm{CP} /$ per ha (tables 1-5). Yield is the dominant factor; therefore, grain sorghum appears poor because of combined lower yields and $\mathrm{CP}$. The higher quality of maize makes it competitive with forage sorghum, if not superior in some cases. Caution should be exercised with interpreting yields of feed nutrients per ha because most plants yield moxe as they approach maturity but decline in quality. Yield of nutrients per ha may be higher at maturity even though the material is unacceptable for animal feeding. This dilemma can be resolved by determining a minimum acceptable percent digestibility irrespective of yield. On this basis cutting the sorghum at the dough stage would not be recommended, but maize could be harvested in the dough stage if yields were increased significantly.

Forage sorghum and maize produced higher DM yields than grain sorghum. Only grain sorghum showed any significant increase in yield as the crop matured. All crops showed a decrease in feeding quality with maturation, as indicated from percent NDF, ADF, IVTD and CP. Maize was, in general, a better quality forage than the forage sorghums, but maize could not compete with the forage sorghums in yields. It would require an increased market value due to its higher quality in order to offset the higher planting costs and lower yields.

The results indicate that some varieties of forage sorghum can be recommended for commercial production on irrigated land of the south 
coast of Puerto Rico. Further research is required before soybean production could be recommended for incorporation as dehydrated forage pellets to enhance protein content.

\section{RESUMEN}

Seis variedades de sorgo forrajero (Sorghum bicolor $\times S$. sudanense) y de sorgo de grano (S. bicolor) y tres tanto de maíz (Zea mays) como de soja (Glycine max) se sembraron en parcelas de 1.2 y $3.7 \mathrm{~m}$ en la Subestación Experimental de Lajas. Todas las parcelas se cosecharon en las etapas de bota, al espigar y granazón, que corresponden a edades de 46, 56 y 81 dias, respectivamente. Los retoños de las variedades de sorgo se cosecharon cada 45 días hasta que cesó el crecimiento.

Se obtuvieron mayores rendimientos de forraje verde y de materia seca con el sorgo forrajero y con el maíz que con el sorgo de grano. Sin embargo, solo los sorgos de grano produjeron un aumento significativo en rendimiento según aumentó la edad de la planta. El valor nutritivo disminuyó a medida que avanzaba la estación. En general, el maíz fue más rico en valor nutritivo que el sorgo forrajero. El maíz requiere una resiembra después de cada cosecha, mientras que el sorgo proveería por lo menos tres retoños antes de que mermara el crecimiento considerablemente. Un perdigón deshidratado de maíz no puede recomendarse, a menos que su alto valor nutritivo sostenga un precio más alto en el mercado. Se discuten los criterios para determinar los valores económicos comparativos de los diversos forrajes.

Los resultados indicaron que el sorgo forrajero se puede recomendar debido a sus altos rendimientos de forraje de buena calidad en los suelos en regadío de la costa sur. Sin embargo, los resultados obtenidos con la soja forrajera fueron pobres. No parece factible producir soja en forma vegetativa para aumentar el contenido proteínico de los forrajeros en perdigones.

\section{LITERATURE CTTED}

1. Akinola, J. O., 1976. A preliminary assessment of forage legumes grown under irrigation for out-of-season dry matter and crude protein production, Herb. Abs. 46: 1651.

2. Brooks, O. L., Miller, W. J., Beaty, E. R., and Clifton, C. M., 1962. Performance of dairy cows fed pelleted and baled Coastal Bermudagrass and alfalfa hay, J. Dairy Sci. 45: $1188-91$.

3. Coward-Lord, J., Arroyo-Aguilú, J. A., and García-Molinari, O., 1974: Proximate composition of 10 tropical forage grasses, J. Agri. Univ. P. R. 58(3): 3-5-11.

4. Edwards, N. C., Jr., Fribourg, H. A., and Montgomery, M. J., 1971. Cutting management effects on growth rate and dry matter digestibility of the sorghum-sudangrass Cultivar Sudax SX-11, Agron. J. 63: 267-71.

5. Goering, H. K., 1976. A laboratory assessment of the frequency of overheating in commercial dehydrated alfalfa samples, J. Anim. Sci. 43: 869-72.

6. Goering, H. K. and Van Soest, P. J., 1970. Forage fiber analyses (apparatus, reagents, procedures and some applications), Agri. Handbook 379, USDA. 
7. Hernández-Urdaneta, A., and McDowell, R. E., 1975. Intensive systems for beef production in the tropics, J. Anim. Sci. 41: 1228-37.

8. Hibbs, J. R. and Conrad, H. R., 1975. Minimum concentrate feeding for efficient milk production, World Anim. Rev. 15: 33-38.

9. McDowell, R. E., Cestero, H., Rivera-Anaya, J. D., Román-García, F., Arroyo-Aguilú, J. A., Berrocal, C. M., Soldevila, M., López-Alberty, J. C., and Metz, S. W., 1973. Tropical grass pastures with and without supplement for lactating cows in Puerto Rico, Agri. Exp. Stn. Univ. P.R. Bull. 238.

10. Morales, A., Unpublished data.

11. Morrison, F. B., 1959. Feeds and feeding, 23rd ed, Morrison Pub. Co., Clinton, Iowa.

12. Riera, A. and Rivera Núñez, J., 1975. La automatización aplicada a los análisis químicos para el diagnóstico foliar, Central Anal. Lab., Agri. Exp. Stn. Univ. P.R., Unpublished guide for technicians, 1975.

13. Snedecor, G. W. and Cochran, W. G., 1967. Statistical methods, 6th ed, The Iowa State Univ. Press, Ames, Iowa.

14. St. Louis, D., 1977. Evaluation of grass hay and sorghum maize, and soybean forage for supplementing pastures in Puerto Rico, Ph.D. Thesis, Cornell Univ., 1977.

15. Vicente-Chandler, J., Abruña, F., Caro-Costas, R., Figarella, J., Silva, S., and Pearson, R. W., 1974. Intensive grassland management in the humid tropics of Puerto Rico, Agri. Exp. Stn. Univ. P.R. Bull. 233.

16. Weding, W. F., 1970. Digestible dry matter, crude protein, and dry matter yields of grazing-type sorghum cultivars as affected by harvest frequency, Agron. J. 62: 35963.

17. Yazrnan, J. A., Arroyo-Aguilú, J. A., McDowell, R. E. and Van Soest, P. J., 1977. Voluntary intake and apparent digestibility of artificially dried Stargrass fed to Holstein bull calves, J. Agri. Univ. P.R. 61: 429-37. 